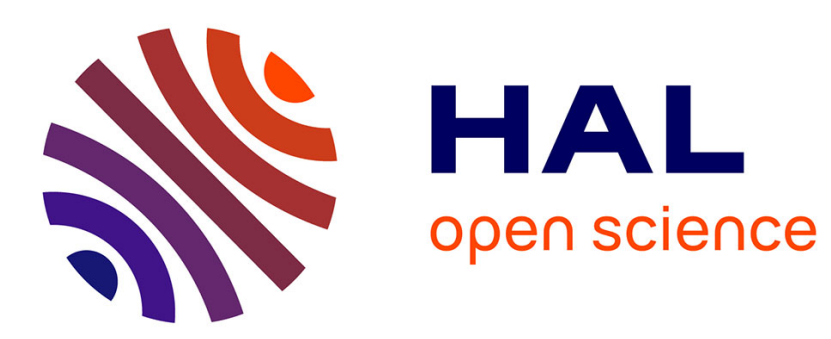

\title{
Is GM Soybean cultivation in Argentina sustainable?
}

Pascale Phelinas, Johanna Choumert

\section{To cite this version:}

Pascale Phelinas, Johanna Choumert. Is GM Soybean cultivation in Argentina sustainable?. 2018. ird-01875358

\section{HAL Id: ird-01875358 \\ https://hal.ird.fr/ird-01875358}

Preprint submitted on 17 Sep 2018

HAL is a multi-disciplinary open access archive for the deposit and dissemination of scientific research documents, whether they are published or not. The documents may come from teaching and research institutions in France or abroad, or from public or private research centers.
L'archive ouverte pluridisciplinaire HAL, est destinée au dépôt et à la diffusion de documents scientifiques de niveau recherche, publiés ou non, émanant des établissements d'enseignement et de recherche français ou étrangers, des laboratoires publics ou privés. 


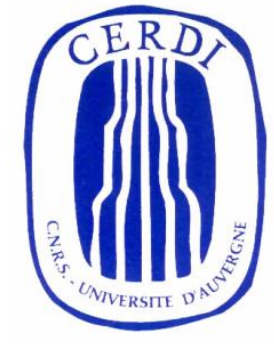

CENTRE D'ETUDES

ET DE RECHERCHES

SUR LE DEVELOPPEMENT

INTERNATIONAL

\title{
SÉRIE ÉTUDES ET DOCUMENTS
}

\section{Is GM Soybean Cultivation in Argentina Sustainable?}

\author{
Johanna Choumert \\ Pascale Phélinas \\ Études et Documents $\mathrm{n}^{\circ} 14$
}

August 2016

To cite this document:

Choumert J., Phélinas P. (2016) "Is GM Soybean Cultivation in Argentina Sustainable?", Études et Documents, $\mathrm{n}^{\circ} 14, \mathrm{CERDI}$. http://cerdi.org/production/show/id/1818/type production id/1

\section{CERDI}

65 BD. F. MITTERRAND

63000 CLERMONT FERRAND - FRANCE

TEL. + 33473177400

$F A X+33473177428$

www.cerdi.org 


\section{The authors}

Dr. Johanna Choumert, Senior Research Manager

Economic Development Initiatives (E.D.I.) P.O. Box 393, Bukoba, Kagera region, Tanzania

E-mail: J.choumert.nkolo@surveybe.com

Dr. Pascale Phélinas, Researcher

IRD-CESSMA-CERDI, 65, Boulevard F. Mitterrand, 63009 Clermont-Ferrand, France

E-mail: pascale.phelinas@ird.fr

Corresponding author: Pascale Phélinas

This work was supported by the LABEX IDGM+ (ANR-10-LABX-14-01) within the program "Investissements d'Avenir" operated by the French National Research Agency (ANR).

Études et Documents are available online at: http://www.cerdi.org/ed

Director of Publication: Vianney Dequiedt

Editor: Catherine Araujo Bonjean

Publisher: Mariannick Cornec

ISSN: 2114 - 7957

\section{Disclaimer:}

Études et Documents is a working papers series. Working Papers are not refereed, they constitute research in progress. Responsibility for the contents and opinions expressed in the working papers rests solely with the authors. Comments and suggestions are welcome and should be addressed to the authors. 


\begin{abstract}
This paper explores the long term sustainability of Argentina's specialization in genetically modified soybean cultivation. It is conceived as an evidence-based assessment of the most relevant economic, social, and environmental, implications of the "soybeanization" of Argentinian agriculture. We combine 2 sources of primary and secondary quantitative data: the National Agricultural Census, and farm level data from a field survey carried out in 2 provinces of the Argentinian Pampas. Our results suggest a major conflict between the success of the "soybeanization" of Argentinian agriculture measured in terms of production and profit records, and the social, economic, and environmental sustainability of this new model of production. GM soybean package adoption has increased farm productivity, and has reduced the costs per unit produced. The resulting dramatic increase in profits constituted a strong incentive to extend the scale of production. The development of companies comprising actors from both agricultural and non-agricultural sectors, constituted a good way to extend the scale of production. But this technological innovation in agriculture has been the source of numerous criticisms. It is widely held among Argentinian researchers, in particular, that soybean expansion has increased land inequality and displaced labor. However overall we find a mixed empirical picture of changing land distribution patterns and labor displacement resulting from the soybean expansion. The environmental implications of agricultural biotechnology are alarming, and the long-term sustainability of GM crops can seriously be questioned. In a context where GM soybean production has become one of the strategic components of Argentina's economy, as well as in the country's international positioning, our results suggest that it is highly unlikely that the government will implement policies against this precious crop and its by-products. However, promoting sustainable agricultural growth has become not only desirable, but necessary.
\end{abstract}

\title{
Keywords
}

Latin America; Argentina; GM soybean; Sustainability; Agribusiness.

\section{JEL codes}

Q13, Q15, Q56, N56

\section{Acknowledgment}

The research leading to this paper received funding from the Agence Nationale de la Recherche (ANR), France, in the program SYSTERRA with reference ANR- 09-STRA-04. 


\section{Introduction}

Agriculture has long been a central activity of Argentina's economy. The country has a big natural comparative advantage for the production of many agricultural products: 33.5 million hectares of arable land, deep and fertile soils, fairly regular rainfall, and direct access to the sea. In 2014, the agrofood sector generated 7\% of the Gross Domestic Product (GDP) while processed agricultural and livestock products accounted for $62 \%$ of total exports. ${ }^{1}$

The transgenic Roundup Ready (RR) soybean was introduced in 1996 in Argentina and, since then has been so rapidly adopted that now Argentina is the most intensive user of biotech seeds in the world. Between 1996 and 2014, production increased at an average rate of $2.4 \%$ a year, mainly at the expense of cattle production, and competing summer crops such as maize, sunflower and wheat. During the last agricultural season (2014-2015), genetically modified (GM) soybean was cultivated on nearly 20 million hectares, which represented $60 \%$ of total land cultivated. The production reached a record of 61 million tons. The oilseeds sector has thus gradually become a strategic sector of Argentina's economy. It contributed in a big way to restoring the macro-economic fiscal balance after the severe Argentinian economic depression of 1998-2002, to generating a large trade surplus and foreign exchange resources, and to supporting economic growth. In 2013, the soybean sector accounted for $24.5 \%$ of total exports of the country. In the same year Argentina dominated the international market for soybean pellets with nearly $57 \%$ of world exports, ahead of the United States and Brazil.

The dramatic productive performance of GM soybean cultivation has been triggered by deep technical and organizational changes, summarized in the expression "el modelo sojero". This model consists of intensive, large-scale, mechanized production, and a very efficient management of farming operations based on new forms of association between farmers known as "pooles de siembra", and leasing services for the main farming operations (Hernandez, 2009).

However, the social and environmental implications of biotechnological agriculture have recently been a source of concern, and its long-term sustainability seriously questioned (Alabaldejo and De Sartre, 2012; Bouza et al., 2016; Carreño et al., 2012; de la Fuente et al., 2006; Gavier-Pizarro et al., 2012; Leguizamón, 2013). Corporate dominance, land concentration, loss of farm jobs, and an increase in income inequality are among the negative socio-economic effects which are most often cited, although these issues are not well documented. Land use change, from forest or pasture, to cultivated land, excessive use of chemical inputs which contamine soils and groundwater, destruction of ecosystems, and erosion of biodiversity, constitute the harmful environmental impacts which have been highlighted (Bouza et al., 2016; Gavier-Pizarro et al., 2012; Pengue, 2005). The emergence of health problems, such as respiratory illnesses or high incidences of cancer resulting from aerial spraying of pesticides have also been reported (Arancibia, 2013; Gallegos et al., 2016).

This paper explores the long-term sustainability of the Argentinian specialization in GM soybean production. Because sustainability is a very multidimensional concept, this paper is conceived as an evidence-based assessment of the most relevant economic, social, and environmental implications of the "soybeanization" of Argentinian agriculture. Our contribution is twofold: first, we combine 2 sources of primary and secondary quantitative data : the Argentinian National Agricultural Census of $2002^{2}$, and farm level data from a field survey carried out in 2011 in 2 provinces of the Argentinian

\footnotetext{
${ }^{1}$ All the quoted figures are calculated from the data bases of the Argentinian National Statistical Institute (Instituto Nacional de Estadística y Censos - INDEC).

${ }^{2}$ For various reasons, the results of the last Agricultural National Census conducted in 2008 are incomplete, and as a result, not published. The last exploitable census was in 2002.
} 
Pampas ${ }^{3}$; second, we adopt a holistic approach by addressing all facets of sustainability. To our knowledge this comprehensive work has never been done before. Our results suggest a major conflict between the success of the "soybeanization" of Argentinian agriculture measured in terms of production and profit records, and the social, economic, and environmental, sustainability of this new model of production.

The rest of the paper is organized as follows. Section 2 discusses the concept of sustainability in agriculture in order to lay the foundations for the succeeding sections. Section 3 to 5 investigate the economic, environmental and social sustainability of GM soybean production. Section 6 discusses the results and policy implications.

\section{What is sustainability in agriculture?}

Sustainable agriculture is a multifaceted concept. Like for sustainable development, there is a variety of definitions for sustainable agriculture. Pretty (1995) acknowledged the difficulty to define it, but several definitions have been proposed over time (Pretty, 2008). However the multiplicity of definitions proposed in the literature makes a definition difficult to use and implement. ${ }^{4}$ Defining the durability of agriculture is all the more difficult due to its multifunctionality. ${ }^{5}$ Although the two concepts are different in the sense that multifunctionality is a characteristic of agricultural systems, whereas sustainability is a goal to achieve (OECD, 2001), their interconnection intensifies the difficulty in providing a clear and useful definition of sustainable agriculture. The following attempts have been made:- "agricultural technologies and practices that: (i) do not have adverse effects on the environment (partly because the environment is an important asset for farming), (ii) are accessible to, and effective for, farmers, and (iii) lead to both improvements in food productivity and have positive side effects on environmental goods and services. Sustainability in agricultural systems incorporates concepts of both resilience (the capacity of systems to buffer shocks and stresses) and persistence (the capacity of systems to continue over long periods), and addresses many wider economic, social and environmental (Pretty, $\quad$ outcomes" 2008, $\quad$ p. 1 ); - or "integrated system of plant and animal production practices having a site specific application that will, over the long term: (a) satisfy human food and fiber needs; (b) enhance environmental quality; (c) make efficient use of non-renewable resources and on-farm resources and integrate appropriate natural biological cycles and controls; (d) sustain the economic viability of farm operations; and (e) enhance the quality of life for farmers and society as a whole" (1990 U.S. Farm Bill in Velten et al., 2015, p. 2).

\footnotetext{
${ }^{3}$ We conducted a survey in July-August 2011 on a sample of 186 farmers owning and/or cultivating 338 plots of land. We collected information on land values, soil quality, accessibility, crops, tenure, etc. The survey was conducted in Junín (Buenos Aires) and San Justo (Santa Fé) provinces. These provinces correspond to the area of two research programs (a European program on the climate, named CLARIS LPB; and a project financed by the French Agency for Research (ANR), named INTERRA) in which a portion of a territory of 110 thousand hectares was randomly selected. Within this territory, each plot of land is referenced. Details of the owner, the producer, type of productive activity, and tenure mode were collected. The database allowed the selection of a simple random sample among producers only (owners who had given up agriculture were excluded).

${ }^{4}$ In a recent review, Velten et al.(2015) examine definitions provided in 129 journal articles and 26 grey literature articles.

${ }^{5}$ According to the OECD, "Multifunctionality refers to the fact that an economic activity may have multiple outputs and, by virtue of this, may contribute to several societal objectives at once. Multifunctionality is thus an activity oriented concept that refers to specific properties of the production process and its multiple outputs". (OECD, 2001).
} 
Other definitions have been provided at the farm level: "For a farm to be sustainable, it must produce adequate amounts of high-quality food, protect its resources and be both environmentally safe and profitable. Instead of depending on purchased materials such as fertilizers, a sustainable farm relies as much as possible on beneficial natural processes and renewable resources drawn from the farm itself" (Reganold et al., 1990 in Velten et al., 2015, p. 2). Other authors concentrate on the sustainable management of resources like land and water resources (Hayati et al., 2010).

To sum up, these definitions focus on an agriculture that meets human needs, today and for future generations; limits its negative impact on natural resources; is economically durable; and is socially acceptable. Our analysis aims to capture different social, economic, and ecological parameters, and to cover both macro and farm levels. At first sight, trade-offs seem to exist between sustainable agriculture and productivity, which challenges the compatibility between these pillars of sustainable development (OECD, 2008; Pretty, 2008).

In the case of GM soybean cultivation, the trade-offs are especially challenging given, on the one hand, its high profitability and its contribution to the Argentinian economy, and on the other hand, its pressure on natural resources. Therefore in the subsequent sections, we thoroughly investigate every facet of GM soybean cultivation in Argentina in order to assess its sustainability, taking into account three dimensions: economic, social, environmental. There are several points of contention about the sustainability criteria for Argentinian agriculture. Does GM soybean cultivation use ecological processes, or does it have adverse environmental impacts? Does it minimize the pressure on resources and harm on human health? Does it contribute positively to the Argentinian economy? Does it favour social cohesion and farmers' livelihoods? It goes without saying that the answers to these questions are not unequivocal, which we will discuss in the following sections.

\section{Economic sustainability}

In order to assess the long-term economic sustainability of GM soybean production, both the farm and the macro levels must be considered.

\subsection{At the farm level}

At the micro-economic level, private profitability ultimately determines whether producing GM soybean will be considered "sustainable" by Argentinian farmers. Most studies have found positive economic returns for the adoption of GM soybean in Argentina, and many authors indicate on average 20 dollars per hectare in cost saving compared to conventional soybean (Craviotti and Gras, 2006; Moschini et al., 1999; Penna and Lema, 2002; Qaim and Traxler, 2005; Trigo and Cap, 2004). Gains in total productivity of $10 \%$ have been reported, as well as the fact that $90 \%$ of the economic value created by the crop is retained by producers (Qaim and Traxler, 2005).This is confirmed in two recent meta-analyses (Finger et al., 2011; Klümper and Qaim, 2014) which stress the better economic performance of GM crop cultivation.

The main benefits of GM technology are a better cultivation process which results in higher yields, and in big reductions in operating costs. Better crop yields arise mainly from the spreading of glyphosate, which facilitates weed management, and considerably reduces the losses related to weed infestation. Savings in operating costs result from mechanization of all farming operations, which saves producers' time performing daily tasks, reduces farm labor requirements by about $30 \%$, and simplifies the management of cultivation operations. In addition, GM seeds and glyphosate are available at low prices, due to the inability of Monsanto to patent its innovation in Argentina. 
Whether these economic advantages can be sustained in the long term remains an open question for many reasons. First, the profitability of GM soybean cultivation is highly dependent on the price of soybean in international markets. The dramatic rise in soybean prices from the end of 2007 to mid2014, due to rising demand in Asian countries, boosted farm profits. However, there is considerable uncertainty about soybean prices which makes it difficult to predict future farm revenues. Prices for most agricultural products are expected to decrease over the next ten years, but they will remain at a higher level than before the peak of 2007-2008 (Organisation For Economic Co-Operation And Development, 2015).

Second, soybean producers also have to face a high export tax which reduces the price they receive compared to the corresponding export price. Between 2007 and 2014, it is estimated that soybean producers received between $60 \%$ and $68 \%$ of the FOB (Free On Board) price (Regúnaga and Rodriguez, 2015). However, due to worsening terms of trade, and in order to boost the country's agricultural output, the new government decided to reduce the export tax by 5 percentage points. Although this significant policy change sounds like good news for soybean growers, it might not have a significant impact on planting decisions because it does not compensate for the $24 \%$ fall in export prices since mid-2014.

A third challenge in the future is related to the high investment costs in terms of seeds, chemical inputs, and machinery incurred by soybean production. The high costs per unit area demand financial solidity in case of adverse events so that the following agricultural cycle is not jeopardized. This has been a key driver of the GM soybean adoption decision, and will continue to be. Farmers with significantly greater financial resources, or those able to attract capital, national or foreign, generally through sowing pools, found GM soybean production profitable and adopted it. Those who lack these abilities have been, and will be, excluded from the sector. The risk is a future concentration of land and production in the hands of some happy few.

A fourth source of concern is future yield decrease due to current agricultural practices that do not follow the recommended crop sequences. Many studies highlight the benefits of crop rotation on yields (Bacigaluppo et al., 2009; Caviglia and Andrade, 2010; Mudgal et al., 2010; Rótolo et al., 2015), and underline the risks of the reduction of soil quality in the long term in the case of monoculture. Continuous cropping of soybean will require an increased use of fertilizer which might turn profits into losses.

\subsection{At the macro-economic level}

From a macro-economic perspective, soybean is a key crop. With a share of $25 \%$ of total exports, the soybean sector makes a positive contribution to the Argentinian trade balance. High export taxes have helped to secure a considerable source of revenue for the public budget.

However, the specialization of Argentinian agriculture on soybean over recent decades has taken place with a growing number of weaknesses and vulnerabilities. First, Argentina's economy remains heavily dependent on soybean. The high concentration of exports on a single crop exposes Argentina to moderate shocks to world commodity prices. The high share of soybean export taxes in the government's revenue (15-20\%) implies that Argentina's debt service sustainability depends significantly on the foreign exchange revenue generated by soybean export earnings. The sharp decline in soybean world market prices since mid-2014 has fueled pressures on public finances and contributed to increasing the fiscal deficit.

Likewise, since more than $90 \%$ of soybean production is exported, the vulnerability of the soybean sector to the economic growth rates and trade policies of importing countries is high. Although 
Argentina has a long list of trade partners ${ }^{6}$, high concentration is observed in destinations: currently nearly $60 \%$ of soy exports are concentrated in 5 markets: China $(22 \%)$, European Union $(21 \%)$, Indonesia (8.5\%), Vietnam (5.7\%), and Thailand (5\%). Argentina's soybean trade surplus is therefore heavily dependent on Chinese demand, and European regulation regarding GM products.

Second, Argentina exports soybean in the form of untransformed products (grain), milling byproducts (pellets), and first-stage processed products (oil). This low level of sophistication of soy export products results in a low unit value for soybean exports. Anlló et al. (2013) estimate that the unit value of cereals and oilseed exports is lower (less than 600 dollars per ton) than the average 4000 dollars for lemon, meat, milk, and tobacco. This suggests that soybean exports do not offer much opportunity for growth and productive employment.

Third, soybean production is rain fed and more sensitive to rainfall anomalies than wheat or sunflower (Hernandez et al., 2015). The growing share of soybean in total production, and area, raises the risk of high dependence on a single climate-vulnerable crop. This may limit the country's ability to face a weather shock, and result in a higher global vulnerability of the agricultural sector to rainfall variability.

Fourth, the soybean model of production is led by large agricultural organisations, commonly called sowing pools, which cultivate hundreds of thousands of hectares. They usually rent land not only in various areas of Argentina, but also in other neighboring MERCOSUR countries (Brazil, Bolivia, and Uruguay). The diversification of production sites allows them to take advantage of different local agronomic conditions, market prices for the outputs, relative operating costs, and political risks associated with each country (Gras and Hernandez, 2013). This strategy has raised concerns about possible moves of capital out of Argentina in case of loss of profitability. The sharp decrease in soybean prices since 2014, combined with rising costs and adverse agricultural policies, have led many sowing pools to reduce the area rented in Argentina, and to relocate production in Uruguay, where it is estimated that $40 \%$ of the land sown to soybean is managed by Argentinian pools (Eleisegui, 2014). Although the short-term impact on local producers who seek to enlarge their farms might be positive, they have lost control of the terms and conditions of their access to land. Little is known about the long-term effects of this changing local embeddedness on economic and social wellbeing.

World demand for soybean is forecasted to grow in the long term, and few countries have sufficient land reserves to expand production to meet this demand, even in the context of increased yields. Argentina (with Brazil, Paraguay and Bolivia) is one of these happy few. Unfortunately, these promising opportunities will increase Argentina's economic specialization in overwhelmingly naturalresource intensive products. This global situation is in the context of the challenges of natural resources conservation, land use sustainability, and good agronomic practices, which are discussed in the next section.

\footnotetext{
${ }^{6}$ Argentinian soybean has been exported to 30 countries during the last five years.
} 


\section{Environmental sustainability}

The agro-industry is essential to the Argentinian economy and is a strong driver of its economic growth. However GM soybean production generates a wide range of environmental externalities. Its long term environmental sustainability has thus been seriously questioned (Alabaldejo and De Sartre, 2012; Bouza et al., 2016; Carreño et al., 2012; de la Fuente et al., 2006; Gavier-Pizarro et al., 2012; Leguizamón, 2013). But some authors do highlight benefits (Brookes and Barfoot, 2005; Burachik, 2010; Viglizzo et al., 2011a; Viglizzo and Frank, 2014), and claim that it contributes overall to sustainability (Burachik, 2010). In the absence of primary data, we provide here an overview of the main impacts of GM soybean production on the environment, with a focus on water and air quality, climate change and land conversion, and soil health.

\subsection{Water and air quality}

The consequences of GM soybean cultivation on water quality have been investigated in several studies (Viglizzo et al., 2011a, 2011b; Viglizzo and Frank, 2006). Agricultural activities need water and at the same time are one of the main sources of water pollution. This pollution is particularly difficult to address because it does not consist of point-source effects. The use of Endosulfan ${ }^{7}$ in soybean cultivation has notably contributed to the pollution of groundwater (Gonzalez et al., 2012, 2010). Intensive agriculture also has adverse effects on air quality. A recent study in Argentina's Pampas (Astoviza et al., 2016) showed a high concentration of Endosulfan in the air.

\subsection{Climate change and land conversion}

Agricultural activities represent $45 \%$ of greenhouse gas emissions in Argentina followed by energy, waste management, and industrial production. Within agricultural activities, the main sources of crop-related emissions are due to the use of agricultural land (98.7\%)(World Bank et al., 2015). On the other hand, some authors argue that the current methods of GM soybean production lead to energy savings, therefore offsetting some negative impacts. ${ }^{8}$ It is worth noting however, that the rapid expansion of GM soybean cultivation has considerably modified the country's natural environment with the expansion of crop land at the expense of natural areas and forests (Bouza et al., 2016; Cabrini and Calcaterra, 2016; Gasparri et al., 2013; Rótolo et al., 2015; Urcola et al., 2015; Viglizzo et al., 2011a).

The issues causing most concern are deforestation, which leads to reduction of biomass carbon stock, habitat destruction, and the depletion of soil phosphorous stocks (Matteucci et al., 2016; Viglizzo et al., 2011a). According to Bouza et al. (2016): "The total loss of ecosystem services due to land-use/cover change (LUCC), wetlands degradation and use of land degrading management practices on grazing lands and selected croplands is about 2007 US\$75 billion, which is about $16 \%$ of the country's GDP". The Argentinian forest area $^{9}$ has decreased over time from $13 \%$ in 1990 to $10 \%$ in 2012. The main drivers of deforestation are agricultural expansion, infrastructure development, and logging. The deforestation has been reinforced by poor enforcement of the Forest Law approved in 2007 (United Nations Environment Programme and GRID - Arendal, 2009, chap. 6), and

\footnotetext{
7 Endosulfan is a pesticide used for soybean cultivation (as well as for sunflower, cotton, corn and vegetables).

${ }^{8}$ See Viglizzo and Frank(2014) for details on energy use intensity in Argentinian agriculture compared to other countries.

${ }^{9 "}$ Forest area is land under natural or planted stands of trees of at least 5 meters in situ, whether productive or not, and excludes tree stands in agricultural production systems (for example, in fruit plantations and agroforestry systems) and trees in urban parks and gardens" (World Development Indicators)
} 
environmental laws (Bouza et al., 2016) ${ }^{10}$. Several researchers (e.g. Moutinho and Schwartzman, 2005) highlight the fact that the immediate benefits of deforestation are big, the net present value of soybean being higher than total revenue from logging, and also higher than the net present value of cattle ranching. Clearing forests for crops such as GM soybean is therefore a profitable option. The deforestation rate is higher in the Northern states of Argentina which have also experienced an expansion of GM crops. This is line with the results of a recent meta-analysis of 117 studies, in which Ferretti-Gallon and Bus (2014) find "that forests are more likely to be cleared where economic returns to agriculture and pasture are higher, either due to more favorable climatological and topographic conditions, or due to lower costs of clearing forest and transporting products to market". Such results are confirmed by Gasparri et al. (2013) who investigated the link between soybean expansion and deforestation in Argentina, with a focus on the Northern Argentine Dry Chaco using data for the period 1972-2011.

\subsection{Soil health}

The introduction of glyphosate and other pesticides for intensive GM soybean cultivation challenges the durability of soil quality and poses questions about health impacts (Astoviza et al., 2016; Burachik, 2010; Urcola et al., 2015). World Bank et al.(2015) report that in Argentina "Desertification and degradation (physical, chemical, or biological) processes have occurred on 60 million hectares of land that produce 50\% of crops and $47 \%$ of livestock, with expected continued losses of up to 650,000 ha/year". However, there is no clear-cut consensus on the specific impact of GM soybean cultivation on soil health. Indeed some authors argue that there are positive impacts from GM soybean adoption thanks to a reduced use of pesticides, and to no-till practices (Klümper and Qaim, 2014; Viglizzo et al., 2011a). In a recent meta-analysis on GM crops, Klümper and Qaim(2014) investigate 147 studies which reported the impact of GM soybean, GM maize and GM cotton, and find that GM technology has led to a $37 \%$ decrease in the use of chemical pesticides.

Continuous cropping of soybean is another source of concern for soil health. Future yields may fall as a result of current agricultural practices which do not follow the recommended crop sequences. As discussed above crop rotation is beneficial for yields (Bacigaluppo et al., 2009; Caviglia and Andrade, 2010; Mudgal et al., 2010; Rótolo et al., 2015) and monoculture could lead to soil depletion. If this depletion occurs, continuous cropping of soybean would require an increased use of fertilizer.

\subsection{Short-term versus long-term concerns}

Simply maximizing short term profits without taking into account the adverse environmental impacts would have a big long term cost for the country (deforestation, land degradation, health impacts, etc.). Several recent research papers provide interesting insights. Using a survey of agribusiness stakeholders and in-depth interviews, Arora et al. (2015) find that landlords tend to favour the long-run, in terms of environment, social, and economic returns. Conversely, tenants are more short-run focused, and care more about immediate benefits. These results are confirmed by several hedonic price studies performed for farmland in Argentina (Choumert and Phélinas, 2015a, 2015b).

\footnotetext{
10 "In November of 2007, the National Congress approved Law 26,331 on Minimum Standards for Environmental Protection of the Native Forests, denominated the "Forest Law"'” (Regúnaga and Rodriguez, 2015). See Bouza et al. (2016) for further discussion.
} 
Finally, to fully account for the impact of GM soybeans, the emergence of health problems, such as respiratory illness or high incidences of cancer, resulting from aerial spraying of pesticides, which have been reported (Arancibia, 2013; Gallegos et al., 2016; Schinasi and Leon, 2014) should be taken into account. It should also be noted that the International Agency for Research on Cancer has classified glyphosate as probably carcinogenic to humans (Group 2A)(IARC, 2015).

\section{Social sustainability: land distribution and employment}

Our analysis of social sustainability is based on a quantitative survey implemented in 2011 in 2 provinces in the humid Pampas region (Buenos Aires and Santa Fe provinces). These provinces are both located in the core zone of GM soybean production, and are representative of Pampas agriculture. They also have similar agro-environmental characteristics.

\subsection{Land distribution}

Many authors have asserted that the expansion of GM soybean cultivation in Argentina has led to land and production concentration (Joensen et al., 2005; Leguizamon, 2016). It is argued that this concentration process has been driven by a decrease in the number of small farmers, and a corresponding expansion of the remaining producers who sought to enlarge their farms. However, data drawn from the last exploitable agricultural census in 2002 does not support the idea of a dramatic increase in land concentration. Admittedly, the number of small-scale farms (less than 500 ha) decreased by $18 \%$ since the previous agricultural census (1988). In fact, the medium-sized farms (between 500 and 2500 ha) benefited from the withdrawal of the smallest. Both their number and share in total cultivated area increased (respectively $4.6 \%$ and $1.9 \%$ ). Conversely, the number of very large farms (more than 10,000 ha) fell by $3 \%$. The area that they controlled slightly increased from $35.8 \%$ in 1988 to $36 \%$ in 2002.

There has been little new information since the last exploitable agricultural census in 2002, and most opinions are based on very limited data. In addition, sowing pools, who operate mainly under informal agreements are not recorded as such in the census, nor in official statistics. It is thus very difficult to gather information about their relative importance. However, reliable sources estimate that they farm no more that $12 \%$ of the total cultivated land (Manciana,2009). Since our survey was designed to capture land rented through sowing pools, we are able to analyze the impact of these arrangements on land distribution.

In the 2 provinces of the Pampas region that we surveyed, average land holding ranges from 232 ha to 404 ha (see Table 1), a size which is quite low by Argentinian standards. This fact tends to support the idea that GM soybean cultivation is neutral as regards size of land holding. Most producers in the Pampas have profitably adopted biotechnologies, even if they do not farm huge areas of land. Tenancy rates are quite high in the 2 provinces surveyed, and land lease arrangements with sowing pools are not uncommon. Farmers rent about $42.6 \%$ of the land they cultivate in Buenos Aires, compared to $53.2 \%$ in Santa Fé. Of this rented land, $30 \%$ is rented through sowing pools in Buenos Aires, 24\% in Santa Fé.

The land distribution pattern is skewed. According to our data $80 \%$ of farms which each have under cultivation less than 500 ha control together $45 \%$ of the total land cultivated. The remaining $20 \%$ of farms control 55\% of the land. To examine the land distribution more closely, we calculated several Gini coefficients which are presented in Table 1. Overall, we find levels of Gini coefficients which indicate a high degree of land concentration. 
Table 1 : Land distribution

\begin{tabular}{|l|c|c|c|c|c|c|}
\hline & \multicolumn{3}{|c|}{ Buenos Aires } & \multicolumn{3}{c|}{ Santa Fé } \\
\hline & $\begin{array}{c}\text { Gini } \\
\text { coefficie } \\
\text { nts }\end{array}$ & $\begin{array}{c}\text { Average } \\
\text { size (ha) }\end{array}$ & $\begin{array}{c}\text { Standar } \\
\mathrm{d} \\
\text { deviatio } \\
\mathrm{n}\end{array}$ & $\begin{array}{c}\text { Gini } \\
\text { coefficie } \\
\text { nts }\end{array}$ & $\begin{array}{c}\text { Average } \\
\text { size (ha) }\end{array}$ & $\begin{array}{c}\text { Standard } \\
\text { deviation }\end{array}$ \\
\hline Owned land & 0.53 & 143 & 140.65 & 0.62 & 253 & 296.30 \\
\hline $\begin{array}{l}\text { Cultivated land on own account } \\
\text { (included land rented on own } \\
\text { account) }\end{array}$ & 0.51 & 194 & 180.52 & 0.63 & 354 & 464.41 \\
\hline $\begin{array}{l}\text { Total cultivated land (including } \\
\text { land rented through sowing pools) }\end{array}$ & 0.46 & 232 & 204.10 & 0.56 & 404 & 469.71 \\
\hline Sample size & \multicolumn{7}{|l|}{112} & & 74 & \\
\hline
\end{tabular}

SOURCE: own calculation based on survey data

To address the question of whether increased tenancy and expansion of production networks worsened the skewedness of land distribution, we compare the concentration of the land owned to the land cultivated on the farmer's own account (owned land plus rented land on own account), and to the total cultivated land (cultivated land on own account plus rented through production networks).

We find more a equal land distribution in cultivated land than in owned land. This means that producers initially endowed with larger land holdings do not increase their operated land much through tenancy. In relative terms, the increase in cultivated land thanks to tenancy is due to the smallest owners. Mean land holding size in the bottom land size quartile is 6 times more than the land owned, while it is "only" $44 \%$ more in the top quartile. The land market is therefore not working against small farmers. However, the results differ significantly depending on what type of rented land is considered in the estimates of land inequality. The Gini coefficients are virtually unchanged when cultivated land on own account is taken into account. Conversely, participation in production networks contributes to a decrease in the dispersion of land holdings: the Gini coefficients decline by $10-11 \%$ when the land rented through sowing pools is added to own land and land rented on own account. Finally, land distribution appears less skewed in the Buenos Aires province, where farmers allocate nearly $58 \%$ of the land they cultivate to GM soybean, than in Santa Fé where soybean is less intensively cultivated ( $37.5 \%$ of cultivated land).

These results, though tentative, provide some indication that land concentration, contrary to a widely held belief, has not and might not worsen over time as a result of the increased share of land devoted to soybean, increased tenancy, and expansion of production networks.

\subsection{Employment reduction}

Did the expansion of soybean production lead to a reduction, or to an increase, in the agricultural labor force? This is now one of the most controversial issues in Argentina. Based on both agricultural and population censuses, several studies have connected the loss in the agricultural labor force during the 1990's to the expansion of GM soybean, and the associated technical changes (Benencia and Quaranta, 2006; Piccinini, 2007; Villulla, 2010). These studies also highlight that the new system of production has stimulated the demand for skilled labor - such as agricultural engineer, accountant, data processing specialist, etc. Other studies, focusing on the global value chains of production, argue that labor displacement in primary operations has been (at least partly) offset by new employment in the services sector, the production of inputs and agricultural equipment, the automobile and financial sectors, etc. (Bisang and Sztulwark, 2006). 
To address the question of whether soybean expansion has had a positive or negative impact on employment, we need to separate the direct employment at the farm level, which is related to the effects of changes in cropping pattern and the intensity of mechanization, from indirect employment within the soybean chain and its connections with other economic sectors.

GM soybean production is by far the least labor-intensive crop in Argentina. Most agricultural operations (ploughing, fertilizing, spraying, threshing, harvesting) are mechanized. Increasingly bigger and sophisticated machines have been designed in order to cultivate large tracts of land, thus reducing working time. The growing use of information technology (to control the level of moisture and the quantity of fertilizer) allows the producer to achieve good monitoring of the production process with very few visits to fields. The adoption of this high-tech farm equipment has sharply reduced the producer's labor requirement, and resulted in a big reduction in the number of days of work needed for farming operations.

To illustrate the impact of GM soybean adoption on the employment at the farm level we use the comparison between Buenos Aires and Santa Fé, since they differ in their agricultural patterns. Table 2 shows several wage employment indicators calculated from our survey. The table also gives the figures for some factors in the employment patterns. Farmers in Buenos Aires obviously create fewer jobs than in Santa Fé. The number of wage workers per farm and per 100 hectares is nearly $30 \%$ less in Buenos Aires than in Santa Fé. Similarly, only 0.5 day of work per hectare and per agricultural cycle is needed in Buenos Aires, whereas farmers in Santa Fé need 0.75 day per hectare and per agricultural cycle.

Table 2 : Some agricultural wage employment indicators

\begin{tabular}{|l|c|c|c|c|}
\hline & \multicolumn{2}{|c|}{ Buenos Aires } & \multicolumn{2}{c|}{ Santa Fé } \\
\hline & Mean & SD & Mean & SD \\
\hline Number of wage laborers by farm & 0.91 & 1.84 & 1.17 & 1.64 \\
\hline Number of wage laborers per 100 ha & 0.25 & 0.68 & 0.34 & 0.28 \\
\hline Number of workdays per ha & 0.54 & 1.21 & 0.75 & 1.09 \\
\hline Cultivated area in total area (\%) & 95.6 & 0.43 & 55.4 & 0.46 \\
\hline Soybean area in cultivated area (\%) & 55.7 & 0.24 & 37.5 & 0.40 \\
\hline Provincial equipment rate & 1.23 & & 0.80 & 0.73 \\
\hline Number of livestock per ha & 0.35 & 0.67 & 0.54 & \multicolumn{3}{|c|}{74} \\
\hline Sample size & \multicolumn{2}{|c|}{112} & & \multicolumn{3}{c}{} \\
\hline
\end{tabular}

SOURCE: Own calculation based on survey data

Provincial differences in labor intensity can be explained by two main factors: a bigger expansion of GM soybean cultivation in Buenos Aires, and the higher intensification of mechanization which is associated with soybean. Farmers in Buenos Aires have decided to get rid of their livestock activity, or to move it to marginal zones in order to devote more area to soybean. As a result, soybean cultivation occupies $55.7 \%$ of the area sown whereas this share is only $37.5 \%$ in Santa Fé where farmers still allocate a large part of their area to livestock. Also, the rate of farm equipment differs strongly between the 2 zones being 1.23 in Buenos Aires and 0.80 in Santa Fé ${ }^{11}$.

Another significant trend in agricultural employment in Argentina has been the qualitative changes in the labor demand. Producers acknowledge that the technological competence associated with the technically advanced productive process is such that it requires qualifications that they

\footnotetext{
11 This rate equals the ratio between the total number of machines in each zone and the total number of farms. Included in the calculation - the three most labor saving machines which are tractors, sowers, and combine harvesters.
} 
usually do not have. They thus call more and more on a qualified labor force to carry out precise tasks, for controlling or monitoring crops, and in management, accountancy, data-processing, etc. Soybean production has thus become a new labor market entry point for highly qualified workers such as agronomists, engineers, and marketing and financial analysts (Gras and Hernandez, 2009).

Table 3 : Distribution of working days (in \%) according to the type of task during one agricultural cycle

\begin{tabular}{|l|c|c|}
\hline & Buenos Aires & Santa Fé \\
\hline Seasonal hired labor (labourers) & 11.1 & 15.1 \\
\hline Permanent hired labor & 88.9 & 84.9 \\
\hline Production technicians & 10.4 & 7.0 \\
\hline Operators of farm machinery & 34.1 & 31.2 \\
\hline Labourers & 44.4 & 46.7 \\
\hline \hline Total hired labour & 100 & 100 \\
\hline Sample size & 112 & 74 \\
\hline
\end{tabular}

SOURCE: Own calculation based on survey data

Our survey data indicates that the distribution of working days according to the type of task performed during a crop year confirms that GM soybean cultivation tends to create high-skilled jobs while low-skilled ones are lost (see Table 3). Buenos Aires has a higher share of working days for the higher qualified roles, such as production technician and farm machinery operator (i.e. workers who not only drive highly sophisticated machines, but also repair them), than Santa Fé. These two categories of workers appear to be the winners in the technical changes in agriculture. Conversely, lower-skilled laborers, seasonal or permanent, appear to be significantly displaced by the intensive mechanization of the production process of GM soybean. Their share represents $44.4 \%$ of total labor days in Buenos Aires against $46.7 \%$ in Santa Fé.

The evaluation of indirect employment is particularly difficult to estimate because GM soybean production and processing (oil and meal) involves many different economic agents. The most important are: input providers for primary production (seeds, fertilizers, herbicides, machinery and equipment); service providers, both on farm (e.g. contractors in charge of cultivation operations), and off farm (e.g. transportation, storage, local and international trading, crushing). Undoubtedly, the new organizational production model of soybean has resulted in the creation of several thousands of small or medium sized new firms, which are scattered all over the producing areas, except the crushing industry which is mostly located at the ports (Regunaga, 2010).

The labor content of these new activities is difficult to estimate mainly because official statistics give employment by industry, but do not isolate soybean. Only a few researchers have looked at empirical strategies for measuring the labor content in the soybean sector (excluding direct cultivation). The two best tentative pictures of indirect employment have been done by Bisang and Sztulwark (2006), and Llach et al. (2004). Although they used quite different methods (respectively value chain analysis and input-output matrix) they reached similar results. According to their calculations, the soybean supply chain employed on average a little less than 200,000 workers in 2005, out of which input and service providers accounted for around 95,000 jobs, transport and commercialization 40,000 jobs, and the agro-industry around 100,000 jobs. If we compare these figures to the total number of workers on soybean farms for the same period, we find that indirect employment represents around $65 \%$ of total employment in the value chain. The multiplying effect on employment (i.e. the extent to which a job created in soybean farming is associated with job increase in the soybean chain), can be expected to be significant. 
However, the strong forward and backward linkages of soybean farming to employment in other economic sectors must not be allowed to hide the fact that the former farm laborers may not have easy access to the jobs created outside agriculture. Moreover, consumption linkages, resulting from the increase in farm incomes, are known to have weak employment effects if agricultural growth is concentrated on medium and large scale farms (Haggblade et al., 2007; Haggblade and Hazell, 1989). This is because in this case, increases in farm incomes do not lead to greater demand for local goods and services, but rather for goods that are more likely to be produced in Buenos Aires or abroad. As a result few employment opportunities are created. Some analysts argue that specialization in soybean production has destroyed indirect employment (Rodríguez, 2005; Villulla, 2009). Previous small shops which used to sell agricultural products and processed agricultural and livestock products to local populations have disappeared, as well as agricultural machinery repair businesses. In the same way, local production of cattle sub-products (e.g. cheese, butchery) has also disappeared. Unfortunately, unskilled former agricultural workers "displaced" by soybean used to depend on these kinds of jobs for their livelihood. As a result, it is likely that GM soybean expansion has brought few if any economic benefits for the poor.

\section{Conclusion}

The objective of this study is to analyse the sustainability of GM soybean production in Argentina, from all perspectives of sustainability. We provide a thorough investigation of conflicting interests and views on the growth of soybean production. We use recent survey data to show that GM soybean production has significant economic, social, and environmental impacts.

GM soybean package adoption increased farm productivity and reduced the costs per unit produced. The resulting dramatic increase in profits constituted a strong incentive to extend the scale of production. The development of companies which combined different actors from both agricultural and non-agricultural sectors, constituted a good way to extend the scale of production. These companies made it possible to gather the resources (land, financial capital, technical skills) essential to the implementation of the very technical GM soybean production.

We find evidence that technological innovation in Pampas agriculture has been the source of fewer socio-economic problems than is usually believed. Although we found big disparities in land distribution, high tenancy rates combined with the expansion of production networks do not increase land inequality. Instead we find evidence that landholding size increased for all strata, the increase being largest in percentage terms for farmers at the bottom end of the land size distribution. In the same way, we found mixed empirical evidence about the labor displacement effect of soybean expansion. On the one hand, the expansion of GM soybean cultivation undoubtedly contributed to reduce labor absorption in agriculture. The technical package introduced by biotechnologies caused the loss of many jobs at the farm level, and a significant shift in demand away from unskilled to skilled labor was observed. On the other hand, numerous jobs have been created in the soybean value chain, for instance in the processing industry, transportation, and storage. Whether they compensated the jobs lost in primary agricultural operations remains an open question, but it is likely that the adjustment to innovation has been particularly painful for former farm laborers who face limited nonfarm employment opportunities. There is a high risk that they remain unemployed and fall into poverty.

Undoubtedly, Argentina enjoys a strong comparative advantage in the production of primary products thanks to its soils (Chisari et al., 1996). This advantage has been increasing in recent years thanks to the performance of the oilseed sector (Bekerman and Dulcich, 2013). GM soybean production has thus become one of the strategic components of Argentina's economy as well as part of the country's international positioning. Given the critical importance of soybean exports for both the 
Argentinian economy and fiscal account balance, it is highly unlikely that the government will implement policies against this precious crop and its by-products. However, promoting sustainable agricultural growth has become not only desirable, but a necessity.

That being said, despite the publication of numerous studies stressing the adverse environmental impacts of GM soybean production, there is no clear-cut consensus on the topic. Overall these mixed results are well presented by Bouza et al. (2016), Qaim and Traxler (2005), and Viglizzo et al. (2011a, 2011b). Stakeholders of the GM soybean agro-industry, as well as citizens, should engage in further research and public debate in order to weigh the overall environmental and health costs of GM soybean against its profit. There remain many concerns about the impact of GM crops on the environment, despite their profitability (Pohl Nielsen et al., 2001). The production of GM soybean will continue to generate debate until the economic/environment trade-off is understood. A consensus is yet to be found. 


\section{References}

Alabaldejo, C., De Sartre, X.A., 2012. Une révolution agricole incomplète? Leçons d'Argentine. Les révolutions agricoles en perspective, 51-72.

Anlló, G., Bisang, R., Campi, M., 2013. Claves para repensar el agro argentino. Editorial Universitaria de Buenos Aires.

Arancibia, F., 2013. Challenging the bioeconomy: The dynamics of collective action in Argentina. Technology in Society, Biotechnology, Controversy, and Policy: Challenges of the Bioeconomy in Latin America 35, 79-92. doi:10.1016/j.techsoc.2013.01.008

Arora, P., Bert, F., Podesta, G., Krantz, D.H., 2015. Ownership effect in the wild: Influence of land ownership on agribusiness goals and decisions in the Argentine Pampas. Journal of Behavioral and Experimental Economics 58, 162-170. doi:10.1016/j.socec.2015.02.007

Astoviza, M.J., Cappelletti, N., Bilos, C., Migoya, M.C., Colombo, J.C., 2016. Massive airborne Endosulfan inputs related to intensive agriculture in Argentina's Pampa. Chemosphere 144, 1459-1466. doi:10.1016/j.chemosphere.2015.10.033

Bacigaluppo, S., Bodrero, M., Salvagiotti, F., 2009. Producción de soja en rotación vs monocultivo en suelos con historia agrícola prolongada. Soja Mejor. Prod 42, 53-55.

Bekerman, M., Dulcich, F., 2013. The international trade position of Argentina. Towards a process of export diversification? Cepal Review.

Benencia, R., Quaranta, G., 2006. Los mercados de trabajo agrarios en la Argentina: demanda y oferta en distintos contextos históricos. Estudios de Trabajo.

Bisang, R., Sztulwark, S., 2006. Tramas productivas de alta tecnología y ocupación. El caso de la soja transgénica en la Argentina. Ministerio de Trabajo, Empleo y Seguridad Social, Trabajo, ocupación y empleo. Especialización productiva, tramas y negociación colectiva, Buenos Aires, Serie Estudios.

Bouza, M.E., Aranda-Rickert, A., Brizuela, M.M., Wilson, M.G., Sasal, M.C., Sione, S.M.J., Beghetto, S., Gabioud, E.A., Oszust, J.D., Bran, D.E., Velazco, V., Gaitán, J.J., Silenzi, J.C., Echeverría, N.E., De Lucia, M.P., Iurman, D.E., Vanzolini, J.I., Castoldi, F.J., Hormaeche, J.E., Johnson, T., Meyer, S., Nkonya, E., 2016. Economics of Land Degradation in Argentina, in: Nkonya, E., Mirzabaev, A., von Braun, J. (Eds.), Economics of Land Degradation and Improvement - A Global Assessment for Sustainable Development. Springer International Publishing, Cham, pp. 291-326.

Brookes, G., Barfoot, P., 2005. GM crops: the global economic and environmental impact-the first nine years 1996-2004.

Burachik, M., 2010. Experience from use of GMOs in Argentinian agriculture, economy and environment. New Biotechnology 27, 588-592. doi:10.1016/j.nbt.2010.05.011

Cabrini, S.M., Calcaterra, C.P., 2016. Modeling economic-environmental decision making for agricultural land use in Argentinean Pampas. Agricultural Systems 143, 183-194. doi:10.1016/j.agsy.2015.12.016

Carreño, L., Frank, F.C., Viglizzo, E.F., 2012. Tradeoffs between economic and ecosystem services in Argentina during 50 years of land-use change. Agriculture, Ecosystems \& Environment 154, 68-77. doi:10.1016/j.agee.2011.05.019

Caviglia, O.P., Andrade, F.H., 2010. Sustainable intensification of agriculture in the Argentinean Pampas: capture and use efficiency of environmental resources. Am. J. Plant Sci. Biotechnol $3,1-8$.

Chisari, O.O., Fanelli, J., Frenkel, R., 1996. Argentina: Growth resumption, sustainability, and environment. World Development 24, 227-240. doi:10.1016/0305-750X(95)00133-W

Choumert, J., Phélinas, P., 2015a. Determinants of agricultural land values in Argentina. Ecological Economics 110, 134-140. doi:10.1016/j.ecolecon.2014.12.024 
Choumert, J., Phélinas, P., 2015b. Farmland rental values in GM soybean areas of Argentina: do contractual arrangements matter? CERDI Working Paper.

Craviotti, C., Gras, C., 2006. De Desafiliaciones Y Desligamientos: Trayectorias De Productqres Familiares Expulsados De La Agricultura Pampeana. Desarrollo Económico 117-134.

de la Fuente, E.B., Suárez, S.A., Ghersa, C.M., 2006. Soybean weed community composition and richness between 1995 and 2003 in the Rolling Pampas (Argentina). Agriculture, Ecosystems \& Environment 115, 229-236. doi:10.1016/j.agee.2006.01.009

Eleisegui, P., 2014. Si pensaba comprar un "campito", hágalo ahora: el precio de la tierra acusa caídas de hasta un 30\% [WWW Document]. iProfesional. URL http://www.iprofesional.com/notas/177197-Si-pensaba-comprar-un-campito-hgalo-ahora-elprecio-de-la-tierra-acusa-cadas-de-hasta-un-30 (accessed 4.23.16).

Ferretti-Gallon, K., Busch, J., 2014. What Drives Deforestation and What Stops it? A Meta-Analysis of Spatially Explicit Econometric Studies (SSRN Scholarly Paper No. ID 2458040). Social Science Research Network, Rochester, NY.

Finger, R., El Benni, N., Kaphengst, T., Evans, C., Herbert, S., Lehmann, B., Morse, S., Stupak, N., 2011. A Meta Analysis on Farm-Level Costs and Benefits of GM Crops. Sustainability 3, 743-762. doi:10.3390/su3050743

Gallegos, C.E., Bartos, M., Bras, C., Gumilar, F., Antonelli, M.C., Minetti, A., 2016. Exposure to a glyphosate-based herbicide during pregnancy and lactation induces neurobehavioral alterations in rat offspring. NeuroToxicology 53, 20-28. doi:10.1016/j.neuro.2015.11.015

Gasparri, N.I., Grau, H.R., Gutiérrez Angonese, J., 2013. Linkages between soybean and neotropical deforestation: Coupling and transient decoupling dynamics in a multi-decadal analysis. Global Environmental Change 23, 1605-1614. doi:10.1016/j.gloenvcha.2013.09.007

Gavier-Pizarro, G.I., Calamari, N.C., Thompson, J.J., Canavelli, S.B., Solari, L.M., Decarre, J., Goijman, A.P., Suarez, R.P., Bernardos, J.N., Zaccagnini, M.E., 2012. Expansion and intensification of row crop agriculture in the Pampas and Espinal of Argentina can reduce ecosystem service provision by changing avian density. Agriculture, Ecosystems \& Environment 154, 44-55. doi:10.1016/j.agee.2011.08.013

Gonzalez, M., Miglioranza, K.S.B., Aizpún, J.E., Isla, F.I., Peña, A., 2010. Assessing pesticide leaching and desorption in soils with different agricultural activities from Argentina (Pampa and Patagonia). Chemosphere 81, 351-358. doi:10.1016/j.chemosphere.2010.07.021

Gonzalez, M., Miglioranza, K.S.B., Shimabukuro, V.M., Quiroz Londoño, O.M., Martinez, D.E., Aizpún, J.E., Moreno, V.J., 2012. Surface and groundwater pollution by organochlorine compounds in a typical soybean system from the south Pampa, Argentina. Environmental Earth Sciences 65, 481-491. doi:10.1007/s12665-011-1328-x

Gras, C., Hernandez, V., 2013. Los pilares del modelo“ agribusiness” y sus estilos empresariales.

Haggblade, S., Hazell, P., 1989. Agricultural technology and farm-nonfarm growth linkages. Agricultural Economics 3, 345-364.

Haggblade, S., Hazell, P.B., Dorosh, P.A., 2007. Sectoral growth linkages between agriculture and the rural nonfarm economy. Transforming the rural nonfarm economy: Opportunities and threats in the developing world, 141-182.

Hayati, D., Ranjbar, Z., Karami, E., 2010. Measuring Agricultural Sustainability, in: Lichtfouse, E. (Ed.), Biodiversity, Biofuels, Agroforestry and Conservation Agriculture. Springer Netherlands, Dordrecht, pp. 73-100.

Hernandez, V.A., 2009. Ruralidad globalizada y el paradigma de los agronegocios en las pampas gringas, in: Gras, C., Albaladejo, C. (Eds.), La Argentina Rural: De La Agricultura Familiar a Los Agronegocios, Sociedad. Editorial Biblos, Buenos Aires, pp. 39-64.

Hernandez, V., Moron, V., Riglos, F.F., Muzi, E., 2015. Confronting Farmers' Perceptions of Climatic Vulnerability with Observed Relationships between Yields and Climate Variability in Central Argentina. Weather, Climate, and Society 7, 39-59. doi:10.1175/WCAS-D-13-00062.1 
IARC, 2015. IARC Monographs Volume 112: evaluation of five organophosphate insecticides and herbicides. International Agency for Research on Cancer. World Health Organization, IARC Monographs Volume 11220.

Joensen, L., Semino, S., Paul, H., 2005. Argentina: a case study on the impact of genetically engineered soya. The Gaia Foundation, London, UK.

Klümper, W., Qaim, M., 2014. A Meta-Analysis of the Impacts of Genetically Modified Crops. PLOS ONE 9, e111629. doi:10.1371/journal.pone.0111629

Leguizamón, A., 2013. Modifying Argentina: GM soy and socio-environmental change. Geoforum. doi:10.1016/j.geoforum.2013.04.001

Llach, J., Harriague, M., O’Connor, E., 2004. La generación de empleo en las cadenas agroindustriales. Fundación Producir Conservando, Buenos Aires.

Manciana, E., 2009. Large-scale acquisition of land rights for agricultural or natural resource-based use: ARGENTINA. Available at SSRN 1915343.

Matteucci, S.D., Totino, M., Arístide, P., 2016. Ecological and social consequences of the Forest Transition Theory as applied to the Argentinean Great Chaco. Land Use Policy 51, 8-17. doi:10.1016/j.landusepol.2015.10.032

Moschini, G., Lapan, H.E., Sobolevsky, A., 1999. Roundup Ready soybeans and welfare effects in the soybean complex.

Moutinho, P., Schwartzman, S., 2005. Tropical deforestation and climate change.

Mudgal, S., Lavelle, P., Cachia, F., Somogyi, D., Majewski, E., Fontaine, L., Bechini, L., Debaeke, P., 2010. Environmental impacts of different crop rotations in the European Union. European Commission, Brussels Final Report. European Commission- DG ENV, 149p.

OECD, 2008. OECD Contribution to the United Nations Commission on Sustainable Development 16 Towards Sustainable Agriculture. The Organisation for Economic Co-operation and Development, Paris.

OECD, 2001. Multifunctionality Towards an Analytical Framework: Towards an Analytical Framework. OECD Publishing.

OECD, FAO, 2014. OECD-FAO Agricultural Outlook 2014. Organisation for Economic Co-operation and Development, Paris.

Organisation For Economic Co-Operation And Development, 2015. Oecd-fao agricultural outlook 2015-2024. Organization For Economic, [Place of publication not identified].

Pengue, W.A., 2005. Transgenic Crops in Argentina: The Ecological and Social Debt. Bulletin of Science, Technology \& Society 25, 314-322. doi:10.1177/0270467605277290

Penna, J.A., Lema, D., 2002. Adoption of herbicide resistant soybeans in Argentina: An Economic Analysis. Buenos Aires, Instituto de Sociología Rural/Instituto Nacional de Tecnología Agropecuaria (INTA).

Piccinini, D.E., Instituto Argentino para el Desarrollo, 2007. Asalariados agropecuarios y campesinos desde mediados del siglo XX: su evolución a partir del análisis de fuentes censales. Realidad Económica (Argentina).(May-Jun 2007), 85-112.

Pohl Nielsen, C., Robinson, S., Thierfelder, K., 2001. Genetic Engineering and Trade: Panacea or Dilemma for Developing Countries. World Development 29, 1307-1324. doi:10.1016/S0305750X(01)00040-7

Pretty, J., 2008. Agricultural sustainability: concepts, principles and evidence. Philosophical Transactions of the Royal Society B: Biological Sciences 363, 447-465. doi:10.1098/rstb.2007.2163

Pretty, J.N., 1995. Participatory learning for sustainable agriculture. World Development 23, $1247-$ 1263. doi:10.1016/0305-750X(95)00046-F

Qaim, M., Traxler, G., 2005. Roundup Ready soybeans in Argentina: farm level and aggregate welfare effects. Agricultural Economics 32, 73-86. doi:10.1111/j.0169-5150.2005.00006.x 
Reganold, J.P., Papendick, R.I., Parr, J.F., others, 1990. Sustainable agriculture. Scientific American $262,112-120$.

Regunaga, M., 2010. Implications of the organization of the commodity production and processing industry: The soybean chain in Argentina.

Regúnaga, M., Rodriguez, A.T., 2015. Argentina's Agricultural Policies, Trade, and Sustainable Development Objectives.

Rodríguez, J., 2005. Los complejos agroalimentarios y el empleo: una controversia teórica y empírica. Documento de trabajo.

Rótolo, G.C., Montico, S., Francis, C.A., Ulgiati, S., 2015. How land allocation and technology innovation affect the sustainability of agriculture in Argentina Pampas: An expanded life cycle analysis. Agricultural Systems 141, 79-93. doi:10.1016/j.agsy.2015.08.005

Schinasi, L., Leon, M.E., 2014. Non-Hodgkin Lymphoma and Occupational Exposure to Agricultural Pesticide Chemical Groups and Active Ingredients: A Systematic Review and Meta-Analysis. Int J Environ Res Public Health 11, 4449-4527. doi:10.3390/ijerph110404449

Trigo, E.J., Cap, E.J., 2004. The impact of the introduction of transgenic crops in Argentinean agriculture. AgBioForum 6.

United Nations Environment Programme, GRID--Arendal (Eds.), 2009. Vital forest graphics. UNEP, Nairobi, Kenya.

Urcola, H.A., de Sartre, X.A., Veiga, I., Elverdin, J., Albaladejo, C., 2015. Land tenancy, soybean, actors and transformations in the pampas: A district balance. Journal of Rural Studies 39, 32 40. doi:10.1016/j.jrurstud.2015.03.001

Velten, S., Leventon, J., Jager, N., Newig, J., 2015. What Is Sustainable Agriculture? A Systematic Review. Sustainability 7, 7833-7865. doi:10.3390/su7067833

Viglizzo, E.F., Frank, F.C., 2014. Energy use in agriculture: Argentina compared with other countries (Chapter 4). In: Energy Consumption: Impacts of Human Activity, Current and Future Challenges, Environmental and Socio-Economic Effects (S. Reiter, Editor). NOVA Science Publishers, Inc. New York, pp 77-98.

Viglizzo, E.F., Frank, F.C., 2006. Land-use options for Del Plata Basin in South America: Tradeoffs analysis based on ecosystem service provision. Ecological Economics 57, 140-151. doi:10.1016/j.ecolecon.2005.03.025

Viglizzo, E.F., Frank, F.C., CarreñO, L.V., JobbáGy, E.G., Pereyra, H., Clatt, J., PincéN, D., Ricard, M.F., 2011a. Ecological and environmental footprint of 50 years of agricultural expansion in Argentina: Footprint of Argentina Agriculture. Global Change Biology 17, 959-973. doi:10.1111/j.1365-2486.2010.02293.x

Viglizzo, E.F., Ricard, M.F., Jobbágy, E.G., Frank, F.C., Carreño, L.V., 2011b. Assessing the crossscale impact of 50 years of agricultural transformation in Argentina. Field Crops Research 124, 186-194. doi:10.1016/j.fcr.2011.05.014

Villulla, J.M., 2010. La política económica de los 90 y sus efectos sobre la organización social del trabajo agrícola, en la pampa Humada 1991-2001. Documentos del CIEA N ${ }^{\circ} 5$ 95-110.

Villulla, J.M., 2009. Problemas y debates sobre la ocupación y el empleo en el agro pampeano de la sojización. Geograficando 5, 127-144.

World Bank, CIAT, CATIE, 2015. Climate-Smart Agriculture in Argentina. CSA Country Profiles for Latin America Series. 